
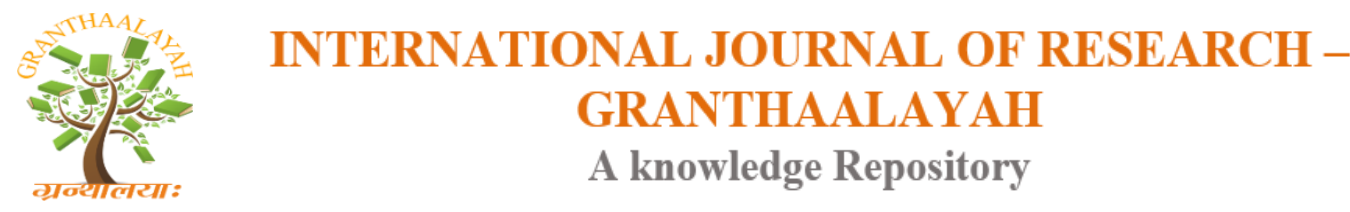

Science

\title{
PETROLEUM GEOLOGY: SCIENCE AND PRACTICE IN THE 21TH CENTURY. NEW IDEAS AND PARADIGMS
}

\author{
N.P. Zapivalov ${ }^{* 1}$ \\ ${ }^{* 1}$ Professor, Trofimuk Institute of Petroleum Geology and Geophysics SB RAS, Novosibirsk, \\ Russia; Novosibirsk State University, Novosibirsk, Russia
}

\begin{abstract}
Nowadays, it is vitally necessary that conceptually new methods be used in petroleum geology. The aim of this paper is to outline new trends and approaches in petroleum geology; to substantiate the necessity for rehabilitation cycles in the process of oilfield development, especially at its active stage; to define the perturbation threshold for equilibrium of a fluidsaturated system. In this paper, an empirical estimation is given of the value of critical perturbation of an equilibrium fluid-saturated system during the oilfield development, equal to formation depression of 5-8 MPa.

The author's conclusion is that at present efforts should be focused on the efficient science-based development of the active oilfields in order to produce the residual (hard-to-extract) oil in a soft, sparing and non-damaging way, as well as on discovering new hydrocarbon accumulations, including secondary ones, throughout the whole stratigraphic section, with all depth horizons and various rock-fluid associations, in regions where a well-developed diversified infrastructure is already available. The use of rehabilitation cycles will make it possible to restore the energy potential of the stratum and filtration properties of the rock. In the long run, it will provide for an increased longevity of the object and higher final oil recovery.
\end{abstract}

Keywords: Origin of Petroleum; «Life» of an Oilfield; Rehabilitation Cycles; Residual Oil; Metasomatism.

Cite This Article: N.P. Zapivalov. (2018). "PETROLEUM GEOLOGY: SCIENCE AND PRACTICE IN THE 21TH CENTURY. NEW IDEAS AND PARADIGMS.” International Journal of Research - Granthaalayah, 6(3), 214-219. 10.29121/granthaalayah.v6.i3.2018.1516.

\section{Introduction}

Making the next giant leap in Petroleum Geosciences!.

\subsection{New Approaches in Petroleum Geology}

In petroleum geology of the $21^{\text {st }}$ century the ideas of modern non-linear dynamics with its concepts of chaos and self-organization begin to dominate. 
Hydrocarbons are reported to occur in all strata of the Earth's crust and are supposed to occur in the cosmic space, too. As to genesis of hydrocarbons, there are various authoritative positions [12].

Owing to his petroleum longevity, the author has left behind the classical organic hypothesis, although it was his personal discovery in 1958 when a specific oil-source rock («Bazhenov suite») was first distinguished in the Upper Jurassic system of West Siberia, based on the study of test wells. It was stated in the author's Ph.D. thesis in 1962. However, now the author holds to a quite different scientific paradigm, which does not imply strict adherence to any of the existing oil origin hypotheses.

The author's position is now that it is almost impossible to create a general all-embracing theory of oil origin. To view regional oil-source rocks as a sole indispensable prerequisite of oil formation is a wrong approach.

As early as in the middle of the $20^{\text {th }}$ century, A.I. Levorsen [3] arrived at the conclusion that oilsource rocks have no concern with actual prospecting and exploration works. In his Geology of Petroleum he stated: «The problem of oil-and-gas origin now loses its significance as a necessary prerequisite in planning the exploration works. The reason is that petroleum-like hydrocarbons are discovered in almost any non-reservoir rocks. The amount of residual oil [micro-oil] dispersed in these rocks exceeds all the proved reserves in the Earth. Therefore, there is no need in search for special source rocks» (in a reverse translation from the Russian edition: Publishing House «Mir», Moscow, 1970, «Conclusion», p. 488).

Various kinds of paleo-reconstructions can hardly be considered a reliable guide in choosing favorable petroleum objects, because each fluid-rock system is subject to secondary, superimposed processes. It is especially important to take into account metasomatic processes. This is why we often deal with young deposits and modern porosity-and-permeability characteristics of a reservoir; their transformation may proceed rather rapidly. The age-analogy principle and the exemplar-based method for evaluation of reserves' categories do not meet the reliability requirements in solving problems of petroleum geology. N.A. Eremenko and G. Chilingar [4] took up the position that in a very short geological time reservoir may turn into a caprock and a caprock into a reservoir.

Oil-and-gas accumulations are traced in all types of rocks and at all stratigraphic levels both onshore and offshore. In fact, we live in a hydrocarbon civilization. Our planet is actually a large overall petroleum polygon.

The myth of «Peak Oil» [5] has been refuted with new evidence and facts [6-7]. Oilfields can be discovered in most unexpected places and conditions. The oil recovery rates depend on various natural, technogenic, and market fluctuations including human factor. A great variety of hydrocarbon sources, both conventional and unconventional, have been discovered and are still being discovered; innovative methods and technologies for hydrocarbon production and utilization are being created; on the whole it shows that the era of hydrocarbon civilization will never end. 


\section{Research, Results and Discussions}

Oil-and-gas-saturated stratum is an integral interrelated system of rocks (minerals) and fluids (oil, gas, and water). An oilfield is a «living»fluid-rock system, subject to the laws of spontaneous autoregulation. It is necessary that research and practical efforts be focused on study and control of the oilfield «life». This «life» depends on a great number of rapidly changing factors with regard to their gradients; oil deposits may be formed, then dissolve, and after that re-generate again. This is why many of oil-and-gas accumulations are young.

During the development of an oilfield, the perturbation threshold for breaking the equilibrium of the oilfield as a fluid-saturated system can be defined with the value of formation depression; there are strong reasons to estimate this critical value of formation depression as 5-8 $\mathrm{MPa}$ [8]. This value is almost universal and applicable for all types of reservoirs.

Fluid-dynamic systems (oilfields, deposits) are in many respects focal and in all likelihood fractal objects with non-uniform productivities.

As a first approximation, dynamics of the states of a hydrocarbon deposit can be described with an evolutionary equation

$$
\frac{\partial \boldsymbol{p}}{\partial t}=Z(\boldsymbol{p}, \boldsymbol{a}, t)
$$

where $\boldsymbol{p}=\left(p_{1}, p_{2}, \ldots, p_{k}\right)$ is a chosen set of dynamic variables describing the system state, $\boldsymbol{a}=\left(a_{1}\right.$, $\left.a_{2}, \ldots, a_{l}\right)$ is a set of the system's parameters, $t$ is time, and $\mathrm{Z}$ is an operator, non-linear in all probability, of the variables $\boldsymbol{p}$, universal for all types (or at least for a sufficiently wide class) of oilfields, which is to be determined on the basis of empirical regularities of the evolution of hydrocarbon accumulations.

This is the usual form for dynamic equations in such spheres as dynamics of mechanical systems, fluid dynamics, theory of classical physical fields, atomic systems, evolution of galaxies etc.; in all these fields, equations of this type make the basis of a successful research of most sophisticated processes and phenomena.

The equations of transfer and balance of hydrocarbon masses and accompanying materials using actual experimental data seem to be the most appropriate basis for constructing full-scale fluiddynamic models. It is especially important in proving the empirical law of critical threshold of perturbation for oil-and-gas-saturated systems, equal to formation depression of 5-8 MPa.

The issue of big oil in the abyssal complexes of West Siberia is not cleared up yet, because of geological ambiguity of the classical term «basement rocks». The author has devoted much effort to solving this problem [9]. A.A. Trifimuk, an outstanding Russian petroleum geologist, used to say that the Paleozoic is «a golden substrate of West Siberia».

In the foreseeable future, the task of large-scale industrial development of Russian Arctic offshore petroleum resources, which are of merely prognostic character, will have to face considerable difficulties and can only help in solving some geopolitical problems whereas the vast on-shore transpolar territory of West Siberia is a quite another, already half-solved problem. 
Bazhenites and shale oil in West Siberia may look inspiring but in fact no breakthrough can be expected here in near future. According to recent data [10], sediments of the Bazhenov formation geochemically belong to metal-bearing black shales; as compared with the world-average values for black shales, the Bazhenov formation is three times richer in $\mathrm{U}, \mathrm{Zn}, \mathrm{Sr}, \mathrm{Ba}$ and 1.5 times richer in $\mathrm{As}, \mathrm{Co}$, and $\mathrm{Tb}$. The concentration of uranium in the rocks is 2 to $171 \mathrm{~g} / \mathrm{ton}$, with the average value $40.9 \mathrm{~g} / \mathrm{ton}$. The resources of uranium in this region can be approximately estimated as 3 billion tons. So, a reasonable question arises whether it may prove commercially viable to produce uranium and other metals from West-Siberian bazhenites, at least in separate promising regions (maybe together with oil).

\section{Conclusion and Recommendations}

At present, forced commercial development of oilfields is being practiced all over the world, in order to quickly produce easy-to-extract oil with the use of all available super-intensive methods and technologies. As a result, the residual oil (reserves) now amounts to 55-70\%. To extract this residual (hard-to-extract) oil from the productive strata, conceptually new ideas and technologies are required.

In petroleum geology, both research and practice (exploration and production) are to be guided by locating zones (foci) of active gradient behavior of fluids at each specific moment of time. Nowadays a lot of such innovative techniques are available, including aerial and space survey. DFM-method [11] and SAM-technology (spectral analysis of microseisms) [12] are highly recommended. These methods make it possible to distinctly determine the highly productive foci during exploration and production of oilfields.

In the process of developing an oilfield and especially at its active stage, it is necessary to use rehabilitation cycles [13-14], in order to restore the energy potential of the stratum and filtration properties of the rock as well as to facilitate fresh formation of hydrocarbon masses. In the long run it will provide for an increased longevity of the object, higher final oil recovery, and beneficial effect for the environment.

Due to various reasons, many wells, separate zones and oilfields have to be abandoned. At such wells and zones, temporary conservation should be performed in order to apply rehabilitation cycles. After that, their renewed development will become possible (for instance, in the Mexican bay, North Sea, West Siberia etc.). This idea found its confirmation in a recent article by I.A. Dyachuk [15]. However re-formation of deposits according to the principle of capillary-gravity segregation seems to be a simplified model: natural processes are much more complicated.

Dolomites in carbonate rock masses formed through late metasomatism are of a special interest. Nano-scale metasomatic processes not only increase porosity and permeability but also often facilitate formation of prolific carbonate reservoirs. It is possible to initiate an accelerated technogenic process of metasomatic dolomitisation in order to create or renew highly-productive foci at an oilfield [16-18].

It is highly desirable to organize research-and-development polygons in various petroleum regions, like the one at the giant Eugene Island oilfield in the Mexican bay (GBRN, Global Basin 
Research Network). In case it proves too expensive, or hard to accomplish for some other reasons, it is necessary to have at least one research well at each active oilfield.

Regular observations are required with constant online monitoring of the current changes inside the fluid-saturated stratum. «To avoid a single error, thousands of observations and thousands of measurements are needed» (Omar Khayyam, a mediaeval astronomer and philosopher). It should be kept in mind that for the Kola Superdeep Borehole in Russia (12 262 meters) many preliminary geological and geophysical models proved inadequate.

Virtual models of various kinds (geochemical, seismic, mathematical etc.) are unable to represent adequately the dynamics of oilfield life. Prof. George E.P. Box, a renowned specialist in mathematical statistics, remarked: «In fact all models are wrong but some are useful» [19].

The same was clearly shown by Xiao-Hui Wu, Senior Earth Modeling Advisor at ExxonMobil Upstream Research Company, in his work «How to Predict Reservoir Performance with Subsurface Uncertainty at Multiple Scales?». He asserts: «It is possible to reduce the source of uncertainty by reducing modeling and numerical errors with the use of parameters based on field data» [20].

Geofluid-dynamic monitoring of the Earth's depths lags much behind cosmic monitoring, and this retardation may prove fatal for civilization.

\section{Practical Recommendation For the Near Future}

At present, efforts should be focused, first, on the efficient well-thought-out development of the active oilfields in order to produce the residual (hard-to-extract) oil in a soft, sparing and nondamaging way (Improved Oil Recovery) and second, on discovering new hydrocarbon accumulations, including secondary ones, throughout the whole stratigraphic section, with all depth horizons and various rock-fluid associations, in regions where a well-developed diversified infrastructure is already available.

Otherwise, huge masses of the already approved residual reserves will remain in the Earth' depths, waiting for future «discoveries» of the already discovered oil.

To handle these problems, the whole potential of science is required; the management of subsurface resources must be science-intensive.

\section{References}

[1] Molchanov V.I., Gontsov A.A. Modelirovanie neftegazoobrazovaniya [Modeling of oil and gas formation]. Novosibirsk: «OIGGM» (United Institute of Geology, Geophysics and Mineralogy) Publ., 1992. - 246 p. (in Russian)

[2] Barenbaum A.A. Nauchnaya revolyutsiya v problem proiskhozhdeniya nefti i gaza. Novaya neftegazovaya paradigma [The Scientific Revolution in the Oil and Gas Origin Issue. New Oil and Gas Paradigm] // Georesources, Kazan, 2014, vol. 59, № 4, pp. 3-9. (in Russian)

[3] Levorsen A. I. Geologiya nefti i gaza [Geology of petroleum]. Mir, «Earth sciences» series, 1970, v. 22. - Editors: Vassoevich N.B., Kalinko M.K. - 638 p. (in Russian)

[4] Eremenko N.A., Chilingar G.V. Geologiya nefti i gaza na rubezhe vekov [Geology of oil and gas at the turn of the century]. Moscow, Nauka Publ., 1996. - 176 p. (in Russian) 
[5] M. King Hubbert. Nuclear energy and the fossil fuels // Drilling and Production Practice (1956) American Petroleum Institute, JUNE 1956

[6] Michael Klare. Peak oil is dead // Oil and Maritime. June, 2014. - P. 36-38.

[7] Daniel Yergin. There Will Be Oil // The Wall Street Journal. - September 17, 2011

[8] Zapivalov N.P. Dinamika zhizni neftyanogo mestorozhdeniya [Dynamics of oilfield life] // Bulletin of the Tomsk Polytechnic University, Tomsk: 2012, v. 321, №1, pp.206-211. (in Russian)

[9] Zapivalov N.P. Kak iskat' i osvaivat' neftyanye mestorozhdeniya v paleozoyskom fundamente Zapadnoy Sibiri (nauchnaya kontseptsiya, opyt, metodika, rekomendatsii) [How to find and develop oilfields in the Paleozoic basement of Western Siberia: theoretical conception, experience, methodical techniques, and recommendations]. Tomsk Department of Siberian Research Institute of Geology, Geophysics and Mineral Resources (SNIIGGiMS): 30 years of geological service in Tomsk. Collected papers. Novosibirsk: SNIIGGiMS, 2002, pp. 157-165. (in Russian)

[10] Rikhvanov L.P., Usoltsev D.G., Ilenok S.S. et al. Mineralogo-geokhimicheskie osobennosti bazhenovskoy svity Zapadnoy Sibiri po dannym yaderno-fizicheskikh i elektronnomikroskopicheskikh metodov issledovaniy [Mineralogical and geochemical features of the Bazhenov formation, West Siberia, according to nuclear-physics and electron-microscopic methods of research] // Bulletin of the Tomsk Polytechnic University, 2015, v. 326, №1, pp 5063. (in Russian)

[11] Pisetsky V.B. Prognoz flyuidodinamicheskikh parametrov basseyna po seismicheskim dannym [Prognosis of fluid-dynamic parameters of a basin based on seismic data]. - Yekaterinburg, Ural State Mining University, 2011. (in Russian)

[12] Vedernikov G.V. Prognoz zalezhey uglevodorodov po kharakteristikam mikroseym [Prognosis of hydrocarbon pools by characteristics of microseisms]: selected papers. Novosibirsk: Publishing House «Svin'in i synov'ya», 2012. - 201 p. (in Russian)

[13] Zapivalov N.P. Pyat' neotlozhnyh mer neftedobychi Zapadnoy Sibiri [Five urgent steps in oil production of West Siberia] // Eko: vserossiyskiy ekonomicheskiy zhurnal [All-Russian economic journal «ECO»]. - Novosibirsk: Nauka Publishing House, 2015, №5, pp. 111-117. (in Russian)

[14] Bednarzhevskiy S.S., Zapivalov N.P., Smirnov G.I. Reabilitatsionnye tsikly nelineynoy dinamiki neftegazovyh mestorozhdeniy kak osnova povysheniya ih produktivnosti [Rehabilitation cycles of nonlinear dynamics of petroleum fields to improve their efficiency] // Nauka i biznes: puti razvitija. - Tambov: TMBprint, 2015, vol. 46, № 4, pp. 27-31. (in Russian)

[15] Dyachuk I.A. K voprosu pereformirovaniya neftyanykh mestorozhdeniy i plastov [Reformation of oil fields and reservoirs] // Georesources, Kazan, 2015, vol. 60, №1, pp. 39-45. (in Russian)

[16] Zapivalov N.P. Innovatsionnye tekhnologii v razvedke i razrabotke neftegazovyh mestorozhdeniy na osnove novoy geologicheskoy paradigmy [Innovative Technologies in Oil and Gas Fields Exploration and Development Based on the New Geological Paradigm] // Georesources, Kazan, 2014, vol. 56, №1, pp. 23-28. (in Russian)

[17] Zapivalov N.P. Metasomaticheskaya dolomitizatsiya i neftegazonosnost' karbonatnyh porod (nanoeffekty obrazovaniya vtorichnyh vysokoproduktivnyh kollektorov) [Metasomatic dolomitisation and hydrocarbon saturation of the carbonate rocks: nanoeffects in formation of highly productive reservoirs] // Nauka i tekhnologiya v Rossii, Moscow: 2009, vol.88, № 2, pp. 31-39. (in Russian)

[18] Pospelov G.L. Paradoksy, geologo-geofizicheskaya sushchnost' i mekhanizmy metasomatoza [Paradoxes, geologic-physical nature and mechanisms of metasomatosis]. Novosibirsk: Nauka Publishing House, 1973. 356 p. (in Russian)

[19] Box, G. E. P. and Draper, N. R. Empirical Model Building and Response Surfaces. - John Wiley \& Sons, New York, NY, 1987. - p. 424

[20] Xiao-Hui Wu. How to Predict Reservoir Performance with Subsurface Uncertainty at Multiple Scales? Society of Petroleum Engineers: Distinguished Lecturer Program, 2015. - Lecture. 